\title{
Sacred Belonging: \\ Writing, Religion and Community in H.D.'s World War II novels
}

\author{
Elizabeth Anderson \\ University of Glasgow
}

\begin{abstract}
:
This paper considers two works from H.D.'s WWII writing, The Gift and The Sword Went Out to Sea. In these texts, H.D. situates herself in the context of diverse intimate communities; her spiritualist circle, her partnership with Bryher, her family and previous generations of Moravians. These communities ground her personal vision of writing as a spiritual exercise that will bring healing to both the individual psyche and the wider society ravaged by war. The significance of community is such that when she becomes isolated, desolation and breakdown follow. The restoration of communication and community through vision and writing leads to healing and a particular understanding of religious modernism as a unity of spiritual and material, transcendent and ordinary.
\end{abstract}

Keywords: H.D., religion, spiritualism, writing, modernism.

word count: 6,718

Contact Details:

Dr. Elizabeth Anderson

Flat 5, 385 Victoria Road

Glasgow G42 8RZ

01414235768

07766711006

s.elizabeth.anderson@gmail.com

Bio:

Elizabeth Anderson completed her PhD at the Centre for Literature, Theology and the Arts and the English Literature subject area at the University of Glasgow in 2011. Her research involves twentiethcentury women's writing, feminist theory and feminist theology. She has published articles in Women: a cultural review and Literature and Theology and is co-editor of Memory, Mourning and Landscape, published by Rodopi, 2010. 


\section{Sacred Belonging: Writing, Religion and Community in H.D.'s World War II Novels}

'I could visualise the very worst terrors, I could see myself caught in the fall of bricks and I would be pinned down under a great beam, helpless. Many had been. I would be burned to death'. ${ }^{1}$ During the London Blitz, the American writer, H.D.'s fear of being buried alive or burnt to death by the falling bombs was met by a fiercely creative force. Between 1940 and 1947 she wrote three novels, three volumes of poetry, a memoir and a collection of poetry and prose, in addition to short stories, poems and numerous letters. At the end of World War II, H.D. suffered a physical and mental breakdown and her creative energy ebbed. ${ }^{2}$ However, she recovered from this desolate period with a renewed sense of her vocation as a writer. Her post-war writing of 1946-47 is both a testament to and a crucial part of her recovery. In considering her substantial oeuvre in the prose reflection 'H.D. by Delia Alton', she commented on the significance of community in her identity as a writer: 'It is the sense of continuity that inspires me, the feeling of intimate communion or communication that renewed my faith at the end of the war-years'. ${ }^{3}$ Continuity with previous generations through memory, visions and rituals, and communion with the spirits of fallen RAF pilots and her companions in the Blitz sound the keynotes of H.D.'s religious belonging. For H.D., this continuity is expressed in 'intimate communion or communication'; inspiration is to be found through intimate connection with others. Rachel Connor emphasises the enabling presence of others to H.D.'s creative and spiritual visions: 'What is significant about . . . all of the revelatory experience H.D. writes about through her lifetime - is that it defines a form of 'spectatorship' or vision that is collaborative, always relying on the presence of another'. ${ }^{4}$ The Moravian Christianity of her childhood and the spiritualism of the World War II years merged 
with her psychoanalytic pursuits and creative activity to yield an idiosyncratic set of beliefs and practices that, for all their particularity, were embedded in religious communities that enabled not only the renewal of H.D.'s faith, but also of her writing.

Like many modernists, H.D. was interested in art's potential as a resource for cultural renewal. However, she did not see art as a replacement for religion, but as a means to, and expression of, spiritual understanding. Neither atheistic nor orthodox, H.D. - like W.B. Yeats, D. H. Lawrence and Mary Butts - exemplifies a third way. Timothy Materer argues that modernist poets engaged in occult explorations 'remain in uncertainties, mysteries, and doubts'. 5 Thus the interest in uncertainty and mystery links modernism with the romanticism of Keats. Exploring mysteries and attending to what is unseen is the overarching concern of H.D.'s mature work. Materer points out that spiritualism (a practice that began in American in the mid-nineteenth century and soon spread to Britain) is only occult when it becomes associated with what is secret or hidden. ${ }^{6}$ H.D.'s interest in hidden wisdom enables her to hold together participation in séances and the secrets hidden within Moravian history and customs. H.D.'s continued interest in the Moravianism of her childhood and her blending of pagan and spiritualist imagery with Moravian rituals and history provides an idiosyncratic approach to spirituality.

In The Gift (1998) and The Sword Went Out to Sea (2007), H.D. uses the spiritual resources of memory, ritual and writing to nurture hope in the face of the traumatic experiences of war. She situates herself in the context of diverse intimate communities - her spiritualist circle, her partnership with Bryher, her family and previous generations of Moravians - thus grounding her personal vision of writing as a spiritual exercise that will bring healing to both the individual psyche and the wider society ravaged by war. The significance of community is such that when she becomes isolated, desolation and breakdown follow. The restoration of communication and community through memory, vision and 
writing leads to healing and a particular understanding of religious modernism as a unity of materialism and spiritualism.

This article focuses on two works from this prolific period, the prose texts, The Gift and The Sword. The typescript of The Gift is dated 1941-1943, with a second section of notes dated 1944 (ix). An abridged version was published by New Directions in 1982, however, scholars usually avoided this text and turned to the longer typescript held at the Beinecke Rare Book and Manuscript Library. In 1998, The University Press of Florida published the complete text of The Gift. In recent years the University Press of Florida has published previously unpublished prose works by H.D., including The Sword, Majic Ring (2009) and The Mystery (2009). The Sword was written in 1946-47 and revised from 1948 to 1950. H.D. was enchanted by this novel and wished for it to be published however she was unable to find a publisher interested in the awkward, complex and difficult text. ${ }^{7}$ Although The Sword was written after the end of the war and is more often compared with H.D.'s other post-war writing, the novel's reflections on war lend it to analysis in the context of her work from the early 1940s. The Sword is a significant text in terms of H.D.'s development as a writer and religious thinker; in it we see a complex engagement with the spiritual, creative and psychoanalytic concerns of her previous World War II writing. Although The Sword has excellent critical introductions, the material is difficult and complex and may be unfamiliar to many readers, so this article attempts to act as an introduction to The Sword as well as indicating some of the wider contexts in which it may be fruitfully read.

Part of H.D.'s enthusiasm for the The Sword sprung from its breadth and complexity. The text touches on H.D.'s memories from World War I as well as World War II. ${ }^{8}$ Moreover, the historical vignettes that form the second half of the volume indicate that the crises that H.D. lived through were connected to the crises of previous centuries and that the spiritual 
renewal that she sought was not just for her own consolation but for the wider war-ravaged world. Marina MacKay argues that many modernist writers 'made the guilty compromise' of supporting World War II despite pacifist leaning and distrust of the type of propaganda and nationalism rife during World War I. ${ }^{9}$ In this way late modernist writing was involved with the public sphere more profoundly than earlier manifestations of modernism. World War II was a markedly civilian conflict and thus many texts, including H.D.'s, may be considered war writing that are more concerned with domestic contexts than battlefields. ${ }^{10}$ Madelyn Detloff considers modernist writing from World War II and the post-war period as 'a constellation of discourses about wide-spread loss and violence'. ${ }^{11}$ Detloff analyses writers (her exemplar is Virginia Woolf) who explore 'the terrain between resignation and redemption' in refusing to transcend trauma or idealise sacrifice but also recognising the possibility of survival and of living into the future. ${ }^{12}$ This resilient writing is evident in H.D.'s prose from the 1940s as she refuses to glorify war or to re-write it into a myth of a challenge overcome. Her myth-making retains a degree of ambivalence and a hope for healing that does not close off the traumatic ruptures in the text. In H.D.'s writing, creative and spiritual practice embedded in intimate communities of both the living and the dead provide a means for consolation and continuing to live.

\section{Haunting and Memory}

Both World War I and World War II witnessed dramatic growth in spiritualism; the bereaved took up 'the paradoxical practice of mourning the dead by refusing to let them die $\ldots$.. as millions of new clients flocked to spirit mediums in hopes of making contact with their dead'. ${ }^{13}$ In this sense, the devotees of spiritualism have more in common with Derrida's melancholic subjects who strive to keep the dead present through discursive openings, than Freud's mourners who seek to incorporate the object of loss or to re-focus libidinal energies 
and so resolve grief. ${ }^{14}$ The ongoing presence of the dead disrupts the consolation that follows incorporating the lost object. H.D.'s texts chart both disruption and consolation, attempting to find a third way between the two in the writing cure. I will return to the practice of such resilient writing after further analysis of haunting and memory in The Sword and The Gift.

Perhaps the most significant difference between spiritualist practice and other forms of haunting is intentionality and desire. A medium may be surprised by the spirits she encounters and what they communicate; nevertheless the presence of the dead is desired and actively sought. In his study of nineteenth-century popular religion, Leigh Eric Schmidt defines 'hearkening' as hearing 'a beckoning voice that requires a reply' or an interior listening: the essential component of spiritualism. ${ }^{15}$ The practice of spiritualism is essentially a process of listening to what the spirits of the dead have to say to the living. Schmidt frames spiritualist discourse as a communal activity, entered into willingly by mediums and spirits and constituting a certain intimacy. It involves both the inner lives of adherents and the external community in the form of the medium's circle. Pamela Thurschwell argues that the fin de siècle fascination with technological modes of communication - telegraphs, telephones, etc. - is related to interest in spiritualism and telepathy as paranormal modes of communication. ${ }^{16}$ As Thurschwell points out, such communication, whether psychic or technological, collapsed distance and enabled new modes of intimacy. This capacity for nontraditional intimacy accords with H.D.'s concern with intimate communities as the vitalising context for spiritual and creative practice.

Colin Davis argues that the living dead - ghosts - destabilise the categories of presence and absence, past and present, life and death. Davis goes on to suggest that in many narratives, the dead return in order to present some requirement. Once this demand has been fulfilled by the living, the ghosts are banished, a second death. Conversely, in other narratives, the disturbance remains; the function of the narrative (and the ghost) is to prevent closure: 
'The tidy restoration of moral and epistemological orders is resisted, as is the clear delineation of the domains of the living and the dead. ... They provide ways of thinking about how, in trauma, sadness or fond memory, we live with the dead' ${ }^{17}$ H.D.'s writing blurs Davis' distinction between narratives of closure and narratives of disruption. In The Sword and The Gift the dead return for a particular purpose (to share visionary experiences, pass on the message of peace and urge the prevention of war) and yet even as this purpose is fulfilled the message given or the gift passed on - they do not fully depart, but instead constitute an ongoing openness in the text. Far from a return to the status quo, the resolution in both novels points to a new future. In The Gift and The Sword, H.D. makes her peace with the dead, and yet continues to attend to them. The figures of fallen RAF pilots, eighteenth-century Moravian and Shawnee leaders and H.D.'s family members linger. They draw together past and present and provide the strength for H.D. to look towards the future.

The protagonist of The Sword is Delia Alton, a pseudonym frequently used by H.D. in her later writing. I will refer to the author as H.D., for clarity and to emphasise the shared authorship of both books, and to the character as Delia for textual accuracy and to emphasise the (always slippery) distinction between author and character. The Sword is a largely autobiographical account of H.D.'s experience as a medium in the 1940s when she received what she believed to be messages from RAF pilots killed in the Battle of Britain. The text describes Delia's attempts to pass on these messages to Lord Howell (a fictional version of Lord Hugh Dowding, the Air Chief Marshal responsible for the victory in the Battle of Britain and himself a spiritualist known to H.D.), her despair at his rejection of the messages, and her subsequent mental breakdown. The rest of the novel contains a series of linked vignettes, drawn from Delia's life and earlier historical eras at times of great change or disaster (ancient Athens, imperial Rome, medieval France and Elizabethan London). Throughout these sections 
a number of characters re-appear in different guises. Delia and Lord Howell are repeatedly refigured as estranged lovers whose eventual reconciliation will bring in a new era of peace.

In her book on spiritualism and modernism, Helen Sword argues that '[v]irtually everything that H.D. wrote during and about the World War II years . . . bears witness to an abiding obsession with otherworldly communication, ghostly return, and the spectral phenomenology of memory'. ${ }^{18}$ Sword goes on to argue that H.D.'s post-war writing, particularly The Sword, shows a marked change from the optimistic writing of the war period itself, due to her post-war breakdown: 'never again would she write so optimistically about prophetic and visionary experience as during the war years'. ${ }^{19}$ While I agree with Sword about the change in tone of H.D.'s writing, I find continuity between The Sword and the works composed between 1941 and 1945 in terms of H.D.'s preoccupation with religious experience and artistic practice in the context of war. The Sword demonstrates H.D.'s ongoing commitment to her vision, tempered with a greater awareness of the risks and personal cost of such commitment. This sense of cost mitigates the optimism of her earlier work, but provides a greater urgency to her sense of vocation.

The RAF pilots' communications to Delia are directed towards political ends, an end to war and prevention of future disasters. H.D. goes on to reiterate her conviction of the interrelation between psychological experience, politics and spiritual realities: 'Probably, it was the struggle to comprehend the incomprehensible actions that were taking place outside, that forced me by a law of compensation, to try to grapple with the forces inside myself, or outside the material world'. ${ }^{20}$ There is a refusal of sentimentality here, an insistence on a practical aim and moving towards the future, rather than mourning the past. It is not Delia's dead who return to her. However, there is a double-haunting in the narrative as Delia's experiences in the séances evoke her memories of World War I, the breakdown of her marriage and eventual deaths of her husband and her brother. ${ }^{21}$ Presence and absence mingle 
as the presence of the RAF ghosts indicates the absence of those dead who are not among their company and the ghosts themselves are present in the spirit and absent in the flesh.

Critical discussions of haunted modernisms repeatedly emphasises the hermeneutical significance of ghosts: 'Ghosts, after all, are hermeneutic entities, both etymologically - like Hermes, the Greek messenger god, they possess a privileged ability to pass between the worlds of the living and the dead - and practically: all ghosts demand interpretation' ${ }^{22}$ In The Sword, H.D. aligns artistic and spiritualist practice, representing the medium as an artist in her own right. Alex Owen argues that spiritualism provided a sphere of power and influence for women (especially in its early period in the late nineteenth century), however, this power is mitigated by the association of the medium with passivity and renunciation of self. ${ }^{23}$ H.D. resists this version of spiritualism. Rather than a passive ventriloquist of the spirits' voices, the medium is a translator, an active participant: 'it had come to me, as a poem or a myth, something that had to be translated' 88 ). As a translator, H.D. is implicitly a member of a community of both living and dead, interpreting one to the other. For H.D., haunting is something to be decoded like other visionary or mystical experiences. ${ }^{24}$ She measures the validity of the spirits' messages against her own understanding, although her reluctance to participate in a more public circle indicates that she may not have been as confident in her own authority as her writing suggests. In these texts, ghosts and memories indicate an excess of meaning, desire and wonder; they are compelling, intrusive and demand action. In The Sword and The Gift, H.D.'s writing is aligned with haunting: as the ghosts seek to pass on messages to Hilda, H.D. or Delia, so H.D. in turn seeks to pass on these messages to the reader. Thus the emphasis in both texts is on the development and maintenance of community through communication. 
In The Gift, memory forms the locus for haunting, for the ambiguous layering of presence and absence and the purposeful confusion of past and present. The Gift oscillates between episodes from H.D.'s childhood in Pennsylvania, narrated by the child, Hilda, and the London Blitz, narrated by the adult writer, H.D. The childhood sections describe experiences that illuminate spiritual and artistic giftedness as rooted in the family and female genealogy. Hilda's grandmother, Mamalie, shares memories of her discovery as a young woman of the 'secret' - a peaceful pact made between Moravian Christian settlers and Algonquian Native American tribes in the eighteenth century. H.D. describes a small group of Moravians and Native Americans as a 'Hidden Church' which recognised the unity of the Moravian Holy Spirit and the Native American Great Spirit. However, this peace was broken and the Hidden Church was lost. ${ }^{25}$ By the end of the novel, H.D. understands her spiritual and creative vocations as unified: to fulfil the broken promise and lost dream through passing on the message of peace in her own writing.

By using two narrative voices, H.D. weaves together the terrors and discoveries of childhood with her adult fears and hopes, providing the key to understanding the gift itself, the legacy that Hilda/H.D. receives from her grandmother. Through Hilda's memories of the intimate world of the Moravian community in Pennsylvania, H.D. constructs a female genealogy in which artistic and spiritual giftedness is entwined. Through her knowledge of music Mamalie understands the secrets of the Hidden Church, which were encoded in musical notations in old documents. When Mamalie shares her memories of the visionary experience she had as a young woman, Hilda stores these memories for later interpretation. The gift is initially defined as artistic by H.D.'s uncle - 'Artists are people who are gifted' - but even this straightforward definition is immediately complicated: 'an artist is someone who - well he can draw or paint or write a book or even do other things' (43). The hesitation and vague reference to 'other things' suggests that the gift is not readily defined and it will take 
Hilda/H.D. the rest of the book to reach a mystical understanding of the gift: 'The Gift was a Gift of Vision, it was the Gift of Wisdom, the Gift of the Holy Spirit, the Sanctus Spiritus' (214).

Helen Sword argues that in H.D.'s World War II writing: ‘memory proves a welcome and redemptive ghost' ${ }^{26}$ However, in The Gift, and even more so in The Sword, there is a negative side to this spectre. Many of the memories evoked in both novels are painful or destructive and must be transformed before they can be redemptive. In the first chapter of The Gift, H.D. suggests that the unconscious carries spiritual inheritance, as well as psychic drives and repressed trauma: 'Shock can also, like an earthquake or an avalanche, uncover buried treasure' (50). For H.D., joyful and painful memories are folded together as her 'war terror' releases memories of childhood trauma, which in turn uncover memories of her spiritual inheritance: 'I had gone down, been submerged by the wave of memories and terrors, repressed since the age of ten and long before, but with the terrors, I had found the joys, too' (219). H.D. links psychoanalysis to her gynocentric genealogy, taking on the spiritual 'gift' of both her grandmother's generation and the eighteenth-century Moravian leader Anna von Pahlen. Anna von Pahlen is a member of the Hidden Church. In The Gift, she exchanges names with the wife of the Shawnee leader, Morning Star. Through Mamalie, H.D. believes herself to be connected to both Anna and Morning Star. It is Anna's voice that Mamalie hears in her moment of vision and H.D. is the recipient of the spiritual gifts of Anna, Morning Star and Mamalie.

\section{Intimate Community}

As Adelaide Morris has aptly noted, H.D.'s poetry has a communal cast from her early work: 'The sustaining pronoun of H.D.'s poetry, however, is not "I" but “we.”, 27 Just as Bryher's presence is necessary to enable and support the visions at Corfu described in Tribute to Freud, so Ben Manisi's support provides the impetus for H.D.'s spiritualist experiences. ${ }^{28}$ The 
communal experience of vision extends to other characters; Hilda's presence draws forth Mamalie's recitation of her earlier visionary experience and the RAF pilots appear as a group.

Throughout H.D.'s writing even the most personal and idiosyncratic visions are embedded in her commitment to community. The Gift focuses on family and Moravian history while The Sword has a broader historical sweep, but each text emphasises the significance of a small, intimate group of fellow believers or practitioners: 'one must, of necessity, begin with one's own private inheritance; there, already the measure is pressed down and shaken together, and running over' [H.D.'s emphasis] (The Gift, 29). ${ }^{29}$ In both texts, H.D. focuses on her place in a small group of initiates nested within a larger community. ${ }^{30}$ In The Gift this is the Hidden Church of the early Moravian immigrants, rediscovered by Mamalie and her first husband and revealed to the child, Hilda. In The Sword, the spiritualist circle of Ben Manisi, Gareth and Delia first provides the necessary group of initiates within the larger group of spiritualists. ${ }^{31}$ Following the breakup of this group, the spirits of the RAF pilots form the community around Delia, although she continues to seek living communion in the form of an alliance with Lord Howell. Howell is figured as part of the group of RAF pilots, partly as a father figure but more specifically through H.D.'s physical descriptions: 'I was looking straight into a white face and staring, grey eyes. ... he looked haunted. He looked like a ghost, anyway’ (36). Describing Howell as a ghost marks the ongoing haunting in the text by constructing a (tenuous) community of the living and the dead, the material and the spiritual.

There is a significant emphasis on choice in both texts as H.D. reiterates her decision to remain in London during the Blitz as a sign of solidarity with her adopted country. In her openness to her own visions and the stories told her by Mamalie and her more active participation both spiritually (as a medium) and materially (by her location in London), she suggests that community belonging is a matter of individual action, not simply historical 
chance. The Gift can be read as a dual deployment of community belonging as Hilda explores her identity as part of a Moravian family in Bethlehem, Pennsylvania and H.D. grapples with the threat to her adult community of London. Towards the end of The Gift, H.D. describes the community forged by the air raids: 'I propped the front-door open and Mrs Williamson across the hall, sent her maid over to see if I were all right . . . People from upstairs came down and people below, dragged out their bedding and slept in the hall' (214).

Bethlehem and London are brought together by psychological and spiritual resonances as the secret of the Hidden Church becomes the means for H.D.'s psychic survival of the Blitz and the continuity of her community. The 'secret' of the Hidden Church is revealed as the promise of intimacy given by Jesus in the Gospel of Matthew, as Mamalie tells Hilda: 'The Secret that my Christian [Mamalie's first husband] explained to me seemed very simple. It was simply belief in what was said - and lo, I am with you alway, even unto the end of the world' (The Gift, 157). The ongoing presence of the Moravian Anna von Pahlen, the Shawnee chief Paxnous, and other members of the Hidden Church indicates not only the significance of maternal genealogy, but of the endurance of this unorthodox communion of saints. The presence of the Hidden Church is marked by moments of visionary consciousness where the mystic becomes one with the spirits of the earlier initiates and is sustained by the telling of this vision. Because she is a musician, it is unsurprising that Mamalie's hearkening to the voices of her spiritual ancestors takes the form of sound and music: 'It was the laughter of leaves, of wind, of snow swirling.... The laughter ran over us and the deep tones of the men's voices and the high pure silver of Anna's voice, mingled in a sort of breathing hymn' (169). The rapture Mamalie experiences culminates in a hymn, the musical expression of her religious community. 
Through identifying herself with these spiritual forebears, Hilda claims the gift of her inheritance. When she hears Mamalie's story, she engages in a complex weaving of names and relationships, situating herself as part of the visionary Hidden Church:

[N]ow I understood that I had another name; now I was Agnes, now I would really be Agnes and Aunt Aggie's name was Agnes Angelica, so perhaps they had named her Angelica because of Anna von Pahlen, then I would be part of Anna von Pahlen, too, and I would be part of the ceremony at Wunden Eiland (163-4). ${ }^{32}$

Only as an adult in war-torn London does H.D. come into a full understanding of Mamalie's gift. The development of Hilda/H.D.'s spiritual understanding is revealed in the narrative form of the central chapter of The Gift, 'The Secret', which contains the episode of Mamalie sharing her memories with Hilda. The narrative is primarily told by the child, but the adult's voice occasionally breaks in, adding a reflective layer to the text in the form of analysis of both Hilda and Mamalie. This dual register suggests that in dwelling on her childhood memories, H.D. is bringing the Hidden Church into the present moment of 1940s London. She goes on to explain that trauma (witnessing her father's injury) caused Hilda to repress Mamalie's secret. The subsequent trauma of the Blitz leads to an 'earthquake' in her mind and the memories are brought to consciousness (50). The presence of the Hidden Church in London is made explicit in the concluding chapter when H.D recognises first England and then the world as Wunden Eiland, a place of sacred belonging: 'Wunden Eiland? Was that this island, England, pock-marked with formidable craters, with Death stalking one at every corner? . . . Our earth is a wounded island as we swing round the sun' $(221,223)$. In linking the war-torn world with a Moravian sacred place, H.D. implies that sacred communities can flourish even in the midst of destruction.

The Sword also concerns the urgency of passing on the message of peace, located in a complex interplay between past, present and future. H.D. reiterates the interconnection 
between individual and social health, suggesting that healing must come from within, radiating outward to others:

I have said if you have consolation, do not try to share it, but eventually, if you are consoled or integrated, you help console and integrate the scattered remnant. I don't think society can be reconstructed from outside. ... In saving oneself, one creates a shell, not the isolated, highly individual spiral-shell I spoke of, but a minute coralshell, one of a million, or a single wax-cell of the honey-comb (67).

In stressing the balance of individual and communal identity, H.D. resists privileging one over the other. Although community belonging is essential for psychic and spiritual health, she emphasises the responsibility of individuals to build and rebuild their communities by attending to the inner life. Therefore her interest in psychoanalysis and psychic health is not a turning away from society but a way of understanding the social world from the inside out.

The importance of intimate communities to H.D. is also emphasised through the negative consequences of their loss. In The Gift we see the threat to community by the physical and psychological destruction of total war as an echo of the massacre of Native Americans after the peace was broken. In The Sword, when communication is interrupted (by Lord Howell), Delia becomes isolated, which leads to confusion, hallucinations and breakdown. Delia sees the disruption of her attempts to form a community with the RAF pilots and Howell as the catalyst for her breakdown. The Gift and The Sword are not purely confessional texts but complex literary constructions in which H.D.'s experience is selectively recounted in such a way as to contribute to her pacifist project. Hogue and Vandivere suggest that The Sword is primarily a work of mourning:

[A] testament to ... the generation of women who saw two world wars and were called "shrill" or mad or both when they tried to protest that war is mad. . . One might say that it is a mad grief - something that looks like madness but isn't, something that is closer to fury. ${ }^{33}$

By writing out the grief and fury of a generation, H.D. attempts to map out a cure. 
The crisis of representation in the twentieth century is largely centred on the issue of trauma - from historical events such as the Holocaust and the Vietnam War to private experiences such as sexual abuse or individual losses - and the tensions around whether and how it may be represented (i.e. whether representations are a fragment of the trauma itself, or whether they are attempts to signal the impossibility of representing trauma), both in terms of literature and history. ${ }^{34}$ Tim Armstrong associates the formal innovations of modernism, particularly its attempts to represent temporal dislocation and lost memory with the trauma of World War I. ${ }^{35}$ The Sword extends the formal innovations of H.D.'s early work to encompass both her prose style and the content of the work by presenting dreams, hallucinations, and a series of interlocked vignettes from the past alongside a fragmented and elliptical narrative voice. Trauma theory intersects with psychoanalytic readings in its interest in such terminology as memory (and forgetting), experience and survival. Luckhurst notes that aside from the vexed question of representation, a particularly fruitful branch of trauma theory attempts to 'find a model of trauma that acknowledges yet seeks to work through the traumatic past, premising communality not on preserving trauma but on transforming its legacy, ${ }^{36}$ In this dynamic model, cultural production, including literature, works to ensure that remembrance does not entail repetition but allows for the emergence of something new. It is in this context that we can place The Sword and The Gift.

Paradoxically, H.D. presents madness as a reasonable response to the terrors of war, while simultaneously presenting Lord Howell as lacking in courage to face up to the consequences of the spirits' visits:

His barbed shaft had not killed me; perhaps, he feared that mine might drive him mad. Madness might do; provided I didn't gibber and hurl things at people, I didn't mind if he thought me a little crazy. But I didn't think I was. Later, I was to reconstruct a world of fantastic terror; I heard sirens and guns, after the war was over. I thought my friends were dead and the city struck down with plague (The Sword, 90). ${ }^{37}$ 
Despite her desolation at Lord Howell's rejection, Delia is here suggesting that her spiritualist experiences are not the result of madness, although her later hallucinations may be. She writes on madness in a dual register, presenting it at one moment as a chosen refuge in which to express her grief and anger and the next moment as a terrifying episode of hallucinations and confusion.

By foregrounding her 'mad grief', H.D. sets the stage for the rest of the narrative to develop various strategies for healing, from the practical (removal from the scene of trauma), to the visionary (Delia experiences consolatory as well as frightening hallucinations). The text becomes a 'recovery document', a text which enacts the writing cure. ${ }^{38}$ The analytic voice emerges early in the narrative, revealing how the changes to the physical cityscape prompt internal upheavals:

The debris that cluttered the streets of London, sometimes left a half-house open. . . I I think this externalization of peoples' private lives, somehow in the end, sliced open one's own house. One looked into one's own interior private life, a life shut off until now, even to oneself (57).

The reversal of inner and outer lives gives psychic and spiritual experiences greater political and social relevance, as well as establishing the reflection on her inner life which will continue throughout the text. Delia's recovery is effected by returning to the distressing symptoms of her illness and seeking to make sense of her breakdown by relating it firstly to her own previous experiences and then to the larger pattern she traces through the historical vignettes. Delia adjusts her purpose from communicating the RAF pilots' message to Lord Howell to the broader project of writing The Sword.

\section{Writing as spiritual practice}

Delia's recovery involves a renewal of her writing; psychic, spiritual and creative health is presented as unified and mutually enabling. In both The Gift and The Sword, H.D. responds to 
personal and social crisis with a deeper commitment to writing. The Gift describes the development of her understanding of her vocation which climaxes in the midst of an air raid:

$[\mathrm{H}]$ ow could I see and be and live and endure these passionate and terrible hours of hovering between life and death, and at the same time, write about them? Yet now ... I passionately regretted only this. That the message that had been conveyed to me, that the message that my grandmother had received, would again be lost (213).

She comes to understand the dual nature of the gift as creative and spiritual and believes that her inheritance is the task of reviving it. Her fear is subsumed by the urgency of passing on the secret of the Moravian and Algonquin peaceful alliance. Likewise, in The Sword, the requirement of passing on the RAF message dominates the novel. The prophetic nature of these messages unites H.D.'s religious thinking and experience with writing.

In both The Gift and The Sword domestic and folk traditions blend with more esoteric practices and elite arts. In The Sword, H.D. uses the tapestry as a metaphor for both her spiritualist work and her artistic endeavour and she refers to the historical tales as Märchen, or fairy tales. The domestic significance of spiritualism is emphasised by the primary object of the work, the table, which forms the locus of the spirits' communication. In a typical move, H.D. layers domestic and artistic life by emphasising that the table used by her circle had formerly belonged to William Morris (The Sword, 9). Folk traditions proliferate within The Gift; pageants, fortune-telling, ballads, fairy tales and homemade Christmas decorations. Mamalie's gift is also rooted in folk traditions; her knowledge of musical composition allows her to decode the messages of the Hidden Church, but her favourite pieces of music are hymns and ballads. H.D. connects 1940s Christmases with her childhood memories; using the fragile but intact decorations as a metaphor for survival: 'look at this, it's as bright as ever and this glass-apple isn't broken' (215). Bill Brown describes 'thing' as a word that 'tends . . . to hover over the threshold between the nameable and the unnameable'. ${ }^{39}$ The ability of things to 
both signify and resist signification allows them to express the nexus of material and spiritual in H.D.'s writing.

For H.D., community belonging is rooted in the mingling of mystical and mundane. She writes about initiates, reincarnation and occult visions - and also of making tea after an air raid and telephoning the neighbours. In the final chapter of The Gift, where H.D. comes into a full understanding of her spiritual inheritance, H.D. lingers over descriptions of her interactions with Bryher during an air raid and emphasises the importance of relationships to survival as her memories of her grandmother overlap with her communion with Bryher. Moreover, she describes her practical preoccupations during an air raid: 'I felt what I had not allowed myself to feel in the days of the first danger, that it would be humiliating to rush out on the winter-street in a pair of worn bed-room slippers' (210). Despite the esoteric tenor of much of her writing, she resists any divorce from material reality: 'we must not step right over into the transcendental, we must crouch near the grass and near to the earth that made us. And the people who created us' (50). Even visionary moments are situated in domesticity: 'I push open the kitchen-door and turn round. I stand by the kitchen-door opposite the mirror, in $a$ glass darkly. But now face to face. We have been face to face with the final realities' (222). ${ }^{40}$ By locating her spiritual visions in domestic reality - the kitchen mirror, handmade Christmas decorations, the William Morris table - H.D. insists on the interconnection of the material and the spiritual.

\section{Conclusion}

Despite her terror during the war and the horror of her post-war breakdown, H.D. structures her narratives to place the emphasis on renewal. She ends The Gift with the affirmation of community: 'they call together to the Great Spirit and the Good Spirit . . . Now they all call together in one voice ... the sound accumulates, gathers sound . . . "It's the all-clear," says 
Bryher' (223). The signal for the end of the air raid, coincides with H.D.'s mystical audition ni which she hears previous generations of Moravians singing, thus bringing together the group of Moravians with the community of London. By closing her narrative with dialogue, H.D. reiterates the centrality of community to her creative project: the voices of the dead sound the note of hope for the future of the living. It is this community belonging that sustains her through her post-war breakdown and provides the impetus to embark on a writing cure that will enable her to record the wars traumas while also asserting her vision of writing as a spiritual and creative task.

\footnotetext{
${ }^{1}$ H.D., The Gift by H.D.: The Complete Text, ed. Jane Augustine (Gainesville, FL: University Press of Florida, 1998) p. 215. H.D.'s tension can be seen in her wartime correspondence. She wrote to Bryher of listening to the news, 'I listen-in the usual 4 times daily. It takes all my energy and time and inbetween,[sic] I try simply to keep myself together' H.D. 'Letter to Bryher, 18 June, 1940'. Bryher Papers, Yale Collection of American Literature: Beinecke Rare Book and Manuscript Library, Yale University, New Haven, CT, 1940.

${ }^{2}$ In her letters to Bryher in 1946, H.D. swings between intense anxiety and calmer reflections on her past and present surroundings. One letter reads 'You may think that I am mad, but I am pretty certain that this apartment is wired throughout .... you must not come here. They may trap us both', while a few weeks later she writes 'Do not worry about Voices, Fido dear. That is all over now': H.D. 'Letter to Bryher, 23 September, 1946'. Bryher Papers, Yale Collection of American Literature: Beinecke Rare Book and Manuscript Library, Yale University, New Haven, CT; H.D. 'Letter to Bryher, 6 October, 1946'. Bryher Papers, Yale Collection of American Literature: Beinecke Rare Book and Manuscript Library, Yale University, New Haven, CT.

${ }^{3}$ H.D., 'H.D. by Delia Alton', Iowa Review 16.3 (1986): p. 195.

${ }^{4}$ Rachel Connor, H.D. and the Image (Manchester and New York: Manchester University Press, 2004) p. 45.

5 Timothy Materer, Modernist Alchemy: Poetry and the Occult (Ithaca and London: Cornell University Press, 1995) p. 4.

${ }^{6}$ Ibid. pp. 16, xii.

${ }^{7}$ Donna Krolik Hollenberg, ed., Between History \& Poetry: The Letters of H.D. \& Norman Holmes Pearson (Iowa City: University of Iowa Press, 1997) pp. 94, 104-05; Caroline Zilboorg, ed., Richard Aldington \& H.D.: Their Lives in Letters 1918-61 (Manchester: Manchester University Press, 2003) pp. 269-270, 280, 295.

${ }^{8}$ For discussion of trauma and H.D.'s World War I writing see Suzette Henke, 'H.D.: Psychoanalytic SelfImaging', Shattered Subjects, ed. Suzette Henke (Basingstoke: Palgrave Macmillan, 2000).

${ }^{9}$ Marina MacKay, Modernism and World War II (Cambridge: Cambridge University Press, 2007) p. 10.

${ }^{10}$ Ibid. p. 6.

${ }^{11}$ Madelyn Detloff, The Persistence of Modernism: Loss and Mourning in the Twentieth Century (Cambridge and New York: Cambridge University Press, 2009) p. 4.

12 Ibid. pp. 14-15.

${ }^{13}$ Helen Sword, Ghostwriting Modernism (Ithaca, New York and London: Cornell University Press, 2002) p. 3.

${ }^{14}$ Jacques Derrida, The Work of Mourning, eds. Pascale-Anne Brault and Michael Naas (Chicago: University of Chicago Press, 2001); Sigmund Freud, 'Mourning and Melancholia', trans. Shaun Whiteside, On Murder, Mourning and Melancholia (London: Penguin, 2005).

${ }^{15}$ Leigh Eric Schmidt, Hearing Things: Religion, Illusion and the American Enlightenment (Cambridge, MA and London: Harvard University Press, 2000) p. 35.

${ }^{16}$ Pamela Thurschwell, Literature, Technology and Magical Thinking, 1880-1920 (Cambridge: Cambridge University Press, 2001) pp. 1-3.
} 
${ }^{17}$ Colin Davis, Haunted Subjects: Deconstruction, Psychoanalysis and the Return of the Dead (Basingstoke: Palgrave Macmillan, 2007) p. 157.

${ }^{18}$ Sword, p. 123.

${ }^{19}$ Ibid. p. 254.

${ }^{20}$ H.D., The Sword Went out to Sea: (Synthesis of a Dream), by Delia Alton (Gainesville: University Press of Florida, 2007) p. 67.

${ }^{21}$ This is a clear example of the fictionalisation of H.D.'s life in The Sword. H.D.'s husband, Richard Aldington, was not killed in the First World War, although they did separate at that time.

${ }^{22}$ Sword, p. 165.

${ }^{23}$ Alex Owen, The Darkened Room: Women, Power and Spiritualism in Late Nineteenth Century England (London: Virago Press, 1989) pp. 6-10.

${ }^{24}$ For an analysis of coding, decoding and hieroglyphics in H.D.'s poetry see Sword, pp. 118-21.

${ }^{25}$ The history of encounters between European Moravians and Native Americans (mainly Lenape, Mahican, Shawnee and other Algonquin groups) is more complex and compromising than The Gift suggests, although the text does not entirely elide the history of conflict. H.D. included a detailed description of massacres of Native American and European Moravians at the hands of hostile tribes and European colonists: H.D., The Gift p. 273. ${ }^{26}$ Sword, p. 124.

${ }^{27}$ Adalaide Morris, How to Live/ What to Do: H.D. 's Cultural Poetics (Urbana and Chicago: University of Illinois Press, 2003) p. 135.

${ }^{28}$ H.D, Tribute to Freud (New York: McGraw-Hill, 1975) p. 47.

${ }^{29}$ See Luke, 6:38.

${ }^{30}$ H.D.'s communities are intimate, but not exclusive, as she writes in Trilogy: 'that way of inspiration / is always open, / and open to everyone' H.D., The Walls Do Not Fall, Trilogy (New York: New Directions, 1998) p. 29.

${ }^{31}$ One may wonder why H.D. did not join one of the circles operating at the Institute for Psychic Research, seeking public legitimisation, as many mediums did. H.D., however, was generally somewhat secretive and defensive about her occult interests and seems to have been concerned about her reputation among friends and colleagues. Majic Ring explores her connection to Manisi/Bhaduri more thoroughly; it was his reference to her own past visionary experiences that led H.D. to trust him and to desire his presence in her circle.

${ }^{32}$ Wunden Eiland was an island in the middle of a river near the Moravian settlement dedicated to the wounds of Jesus, and, in The Gift, the meeting place of the Hidden Church.

${ }^{33}$ Cynthia Hogue and Julie Vandivere, 'Introduction', The Sword Went out to Sea: (Synthesis of a Dream), by Delia Alton (Gainesville: University Press of Florida, 2007) p. xv.

${ }^{34}$ Roger Luckhurst, The Trauma Question (London and New York: Routledge, 2008) p. 12. For further discussion of the representation of trauma in history writing, see Dominick LaCopra, Writing History, Writing Trauma (Baltimore: The Johns Hopkins University Press, 2001). Some studies, such as Detloff's The Persistence of Modernism, attempt to bridge the discourse on traumas that are public and communal vs. those that are private and isolating: p. 13.

${ }^{35}$ Tim Armstrong, Modernism: A Cultural History (Cambridge: Polity Press, 2005) p. 19. MacKay makes a similar point, although she cautions against a too simplistic identification of formal experimentation and anticonservative politics: MacKay, pp. 7-9.

${ }^{36}$ Luckhurst, p. 213.

${ }^{37}$ I use the word 'madness' here deliberately, partly because H.D. uses it herself in the course of The Sword, but also in order to avoid an anachronistic use of clinical language.

${ }^{38}$ Jane Augustine, 'Preliminary Comments on the Meaning of H.D.'s the Sword Went out to Sea', Sagetrieb 15.1-2 (1996): p. 130.

${ }^{39}$ Bill Brown, 'Thing Theory', Critical Inquiry 28.1 (2001): pp. 4-5.

${ }^{40}$ See I Corinthians, 13:12. 